\title{
Academic Status for College and University Librarians-Problems and Prospects
}

\begin{abstract}
Academic librarians will achieve and deserve full academic status only after they cause changes in the bureaucratic structure of libraries and in library education, and when they provide professional service on a scholarly level.
\end{abstract}

C

MOLLEGE AND UNIVERSITY librarians have not enjoyed overwhelming success in their efforts to secure full academic status. ${ }^{1}$ With only a few exceptions, the benefits of academic status have been superficial; substantive areas-salaries, research support, self-direction on the job, voice in academic policy and practice, peer evaluation-have not really been touched. The reason is because librarians have had great difficulty in demonstrating to the academic community, and frequently even to themselves, that they perform a function justifying full academic status.

The situation is now changing. Not only do the new information demands and problems of the academic community provide an opportunity for the librarian to assume a role that is as sophisticated, demanding, and necessary as any other within that community, they require that he do this or step aside so someone else can take over this function. Furthermore, it is becoming clear that full academic status will not be simply an outgrowth but a necessary

Mr. Smith is Head, Search Division, Acquisition Department, at the University of California at Berkeley. concomitant of his assumption of this role. Consequently, this is an opportune time to look once again at the problem of academic status for librarians, to gauge how it may be achieved, the obstacles that remain, and what is in store for librarians if they do not achieve it.

Any consideration of academic status must begin with an appraisal of the academic community, its structure and value system. John J. Corson, in his analysis of college and university organization, notes that it has "two structural arrangements operating to a large degree on a parallel basis," each of which fulfills a different function. ${ }^{2}$ On the one hand, there is the "academic" segment, composed primarily of faculty members, and organized into departments and schools. These are the specialists who perform the primary teaching, research, and public service functions of the institution. ${ }^{3}$ They are "not a subordinate level of workers operating under a structure of hierarchical authority [but they] exercise individual and collective responsibility for the conduct of the learning and research process." ${ }^{4}$ They evaluate each other's performance through review committees and, meeting together as a council or senate, they determine 
the educational policy of their college or university. ${ }^{5}$

The second or "nonacademic" structure is quite different. It follows the classic "line" organizational pattern of a bureaucracy. ${ }^{6}$ It includes managerial, clerical, and maintenance personnel who keep the records, operate the business offices, and perform custodial functions. Such personnel carry out, according to well-established routines, decisions made by administrators. This double structure is coordinated by the president, chancellor, deans, and department chairmen-administrators with academic backgrounds or practicing academics who also perform a part-time administrative role.

This structure and the roles of its component elements have evolved over time, characterized by steadily increasing specialization and diversification. Until 100 years ago, the professor was "an intellectual generalist who might at once profess natural history, ethics, and theology while remaining a Latin or Greek scholar."' College faculties were small and performed most of the institution's managerial as well as educational functions.

During the past century, however, both the nature of the college or university and the role of the professor have undergone significant changes. Educational institutions have become "pluralistic" combinations of "diverse structures, programs, and personnel." 8 The faculty member has changed from a generalist to a specialist. There has been "a progressive decline of his characterdeveloping function along with a strong tendency for the research and informational functions to part company and form two separate callings." His orientation has become primarily "professional as opposed to institutional." 9

One of the most significant outgrowths of this situation has been the appearance of a growing number of professional specialists, researchers, counsel- ors, program developers, and many others who perform highly skilled functions that were once carried out by the faculty as part-time activities or which did not exist until recently. These specialists occupy a kind of no-man's-land. While the sophistication of their work is unquestioned, and while their contribution to the educational, research, and public service activities of their institutions is becoming more pronounced and essential, they have not generally been accepted as full-fledged members of the "academic" community. ${ }^{10}$ The trend, however, seems to be in this direction. Certainly the academic community is coming to recognize that successful education, research, and public service in the modern world require an increasing array of highly qualified personnel, all of whom make essential contributions to the academic enterprise.

Among such personnel, librarians occupy perhaps one of the most ambiguous positions. Originally a custodial function carried out by faculty members in spare moments, academic librarianship has become a full-time occupation requiring special graduate education. ${ }^{11}$ Yet despite its educational requirements, librarianship has not been widely accepted as an academic activity. Much of this is due to the approach that librarians have taken to their responsibilities.

By concentrating their efforts on the more routine aspects of library operation, by emphasizing institutional goals, and by adopting bureaucratic organizational patterns, college and university librarians have effectively aligned themselves with the nonacademic segment of their communities. Even librarians who have most vigorously advocated their acceptance as full-scale academics have recognized the serious defects in the image they present to those who must accept them into partnership. They note, for instance, that most faculty are unable to distinguish between members 
of the clerical and professional library staffs when they contact them. ${ }^{12}$ Unfortunately, the full implications of this situation-the need to realign functions within the library and to concentrate on expanding sophisticated professional service-have only recently been clearly perceived. Prospects for such changes seemed remote in the past; they now appear not merely attainable, but necessary. There are several reasons for this.

Fundamental changes are taking place in modern education. With the growing stress on self-direction and research for the undergraduate student, instruction is moving beyond the confines of the classroom and into the informal conference, the laboratory, and the library. ${ }^{13}$ At the same time, faculty and graduate research is becoming increasingly complex, with a rapidly growing volume of material to absorb in every field, even as the urgency to cover that material and accomplish the research quickly also intensifies. Social demands continue to broaden the areas of research and instruction.

Such developments have brought a new importance to traditional library activities. The great volume and variety of scholarly and informational publication that is a direct outgrowth of contemporary research is making bibliographical control both more demanding and more necessary. ${ }^{14}$

Major advances are being made in descriptive bibliographical control by inter-institutional cooperation. ${ }^{15}$ Hopefully, these will be extended and supplemented by more of what one writer has termed "exploitive control ... the 'special' library serving a group of scholars accustomed to talk to each other, and staffed by persons approaching the type of the bibliographical consultant rather than the bibliographical aid."16 Such consultants can provide service tailored to a library's specific clientele, such as the compilation of special bibli- ographies and information about new publications, and can fill in the gaps in more formal bibliographical coverage through publication. ${ }^{17}$ In this respect, the bibliographical consultant would also become a bibliographical scholar.

The explosion of knowledge and publication is also making in-depth reference or information service a prime necessity in sophisticated educational and research programs. With the growing emphasis on individual study, libraries will be expected to provide such service to scholars and students who are becoming less bibliographically self-sufficient even within their specialties. ${ }^{18}$ Moreover, as information developments make a moderate skill in library research almost a necessity for every educated person, academic librarians must assume a more formal instructional role in their colleges and universities, teaching students at least its more rudimentary principles.

One of the most heartening developments in academic librarianship is the increasing assumption of collection-development responsibilities by librarians. Not only are faculty members increasingly reluctant to continue to bear this responsibility in addition to their teaching, research, and committee work, but collection development is itself becoming so specialized and demanding that it is unmanageable for anyone except an expert who combines a knowledge of the field with a specialty in its bibliography and in library practice. Indeed, a corps of such specialists who work within each of the scholarly disciplines as well as together in developing the overall library collection program can rationalize that program and tailor it to the needs of the institution in ways never possible before. ${ }^{19}$

Such developments are making it possible not only for the academic librarian to assume substantially important functions within the academic community but to achieve full partnership there. As 
he provides formal classroom instruction in library research and more personalized informal instruction through indepth reference, as he shoulders the responsibility of bibliographical scholarship, as he cooperates actively in research and education programs through collection development and specialized bibliographical coverage, he moves toward full parity in the teaching, research, and public service functions. Under such circumstances, as Charles E. Bidwell recently noted, "some of the endemic problems of academic librarianship will be swept away; for example, the indifference of the faculty or the marginal status of the librarian." ${ }^{20}$ Moreover, the librarian will do this not by aping the faculty but by performing a complex and necessary service that no one else in the academic community is qualified to provide.

Yet serious obstacles remain. A crucial problem is the bureaucratic structure of libraries, which emphasizes institutional goals and loyalties. Professional service functions must be made clearly primary, and distinguished from nonprofessional, secondary institutional functions. ${ }^{21} \mathrm{Li}$ brarians must transform their hierarchical, bureaucratic junctions with each other into collegial, professional relations.

This means that decision-making in such matters as collection development, bibliographical control, and information service must be within the discretion of the individual expert practitioner, acting within a collegial framework, and restricted only by the most necessary institutional restraints. Supervision of professional activity must be abandoned and replaced by general administrative coordination and peer evaluation. Rewards must be based primarily on professional accomplishment, not bureaucratic position; academic benefits must be substantial enough to attract, keep, and develop topflight personnel.

A second problem is evident from a recent study, which showed that the profession does not generally attract the highest level of student, that it is unable to keep many of the best that it does attract, and that it contains a high proportion of people who have little commitment to advancing their field of activity-women for whom librarianship is a secondary function, men who have tried several fields before settling into one which presents fewer challenges or who sought such from the beginning. ${ }^{22}$ Considered in relation to faculty and research personnel, what is most wanted is the dynamic, creative individual who is serious about the work he does, its importance, and his own decisive role in performing it.

This means librarians who do not simply accept direction or depend upon routine but who will question what they do and how they do it, and who will attempt to enlarge and perfect their field, its theory and practice. It also means librarians who will involve themselves with the rest of the academic community not as handmaidens but as partners.

A third problem involves changes in library education. The Committee on Research Libraries of the American Council of Learned Societies, in its report to the National Advisory Commission on Libraries, noted that "an increase in the number of trained librarians would not necessarily meet the distinctive requirements of research libraries." Rather, library schools must begin to "produce the rare hybrid that every research library seeks, the librarian-scholar, either by divided graduate programs or by courses in librarianship specifically designed for linguistic or area specialization." 23

This statement has several implications for academic librarianship. First, it stresses the need for more librarians with specialized knowledge. Unfortunately, it perpetuates an old shortcoming by its altogether too-limited view of 
the kind of specialization that the modern academic library needs. Library schools must, of course, produce graduates who are much more knowledgeable in subject and area bibliography, but they must also produce specialists who have a sophisticated knowledge of the bibliography of maps, government publications, and other special materials. They must also produce graduates who are knowledgeable in scientific management, organization theory, social psychology, and other pertinent fields so that they can administer the complex activities of the modern academic library.

Second, the statement points up the need for more stress on substantial theory in library education. Where, in the past, library schools have placed emphasis on cataloging practice, they should now stress the theory and practice of bibliographical control, of which cataloging is only one increasingly narrow and routine part. Where they have taught lists of reference titles, they must now stress the theory and practice of information service, including the evaluation of client needs and the techniques of locating the information that most suits those needs.

Third, the committee has highlighted the importance of interdisciplinary education. Neither library schools nor graduate subject programs are presently educating the "scholar-librarian" that the research library needs. Only coordinated programs, in which the subject field provides the subject education and the library school the bibliographical and information-process training, will answer this need.

Finally, the committee's statement raises once again an old bugbear of library education: quality vs. quantity. For a number of years, in the mistaken belief that libraries require a vast herd of additional professional personnel, the schools have produced a large number of poorly educated graduates. Academic libraries do not need a great many additional professionals. If anything, they have too many librarians now: most of them spend the bulk of their time doing clerical work which nonprofessional personnel can perform equally well for substantially less money. What academic libraries do need is fewer but better-educated librarians who can step into the collection-development, substantialreference, and bibliographical-consultant positions that are now largely unfilled.

Library educators have demonstrated an awareness of these problems for some time; however, they have moved rather slowly toward solving them while they have continued to debate their merits.. ${ }^{24}$ Now some important steps are being taken to improve library education through more emphasis on divided programs, particularly within the compass of the developing sixth-year specialist programs. ${ }^{25}$ Such efforts must be accelerated. At the same time, the old fifthyear programs should be abandoned or drastically revised for academic librarians. Certainly, the generalist approach is no longer applicable to the education of the sophisticated specialists that research libraries require.

Even if the problems of organization, personnel, and education are solved, academic librarians will still have to overcome the strong tendency toward exclusivity within the academic community. Those who have academic status keenly remember the long and difficult education they underwent to gain admittance themselves, and they highly esteem the substantive work they do to maintain their position. An academic's perfectly proper jealousy does not make it easy for others, who may have somewhat different qualifications and functions, to become full-fledged members of the academic club.

Faculty members have, however, demonstrated a willingness to welcome as colleagues those librarians who pos- 
sess bibliographical expertise in specific fields, particularly when such expertise is scholarly and is based on substantial formal education, including graduate work. Thus, for example, a librarian specialist in African studies, with advanced degrees in that field as well as in librarianship, who is involved in an area studies program-coordinating collection development, extending bibliographical control tailored to the program, instructing students in how to do research in the literature, and doing research himself that is oriented toward improving the control or use of the literature-is functioning as a full academic peer of the African studies faculty. Furthermore, the librarian soon makes it evident that he is a very essential part of the program. Where librarians have functioned in this way, faculty response, which may have been quite skeptical at first, has become enthusiastic. ${ }^{26}$ Furthermore, in studies of faculty attitudes toward library service and the status and role of librarians, it is this kind of librarian that they have requested and it is this kind of librarian that they have been willing to recognize as a fullfledged academic colleague. ${ }^{27}$

College and university administrators must also approve the granting of academic status. This is usually the last and decisive step, and it may also prove to be the most difficult, because administrators rightly perceive higher costs in higher status. It will be crucial to have faculty support: influential pressure, based on an awareness and appreciation of high-quality service from specialist librarians, may well determine the outcome.

Academic and professional library organizations will have to provide more active support; it is unfortunate that these associations have not done more to help librarians deserve and achieve full academic status.

Obviously the changes outlined in the preceding pages are not going to be easy. They will require considerable commitment, planning, risk taking, and a willingness to relinquish old ways. On the other hand, perhaps the greatest strength in the academic librarian's drive for improved status, as Goode noted in a somewhat different context, is that many of the crucial decisions are in his own hands..$^{28}$ The reorganization of libraries, the revision of library education, the expansion of professional service and the reallocation of responsibilities within libraries-these are matters that are largely within the province of the profession. Some expansion of benefits to librarians, such as more time for research, more professional involvement, additional leaves, some salary adjustment, are also possible in most academic libraries without outside approval. It certainly is true that as long as librarians treat each other as nonprofessional and nonacademic bureaucrats, they will retain just that status within the academic community.

It is time, also, that librarians recognized that academic status is much more than a matter of position or benefits. It is closely tied to their present and future role in higher education. Unless they assume responsibility for providing the bibliographical and information service that is crucially needed in colleges and universities, others will be called in to do this and the librarian's status problem will be solved once and for all in a way that he does not want.

\section{REFERENCES}

1. The literature on the academic status of librarians is voluminous. A good recent survey is provided by Florence Holbrook, "The Faculty Image of the Academic Librarian," Southeastern Librarian, XVIII (Fall 1968), 174-193.

2. Governance of Colleges and Universities (New York: McGraw-Hill, 1960), p. 34-35.

3. Robert H. Knapp, "Changing Functions of the College Professor," in The American College, ed. by Nevitt Stanford (New York: John Wiley, 1962), p. 290-311.

4. John D. Millett, The Academic Community (New York: McGraw-Hill, 1962), p. 105.

5. Corson, p. 35.

6. Ibid. 
7. Knapp, p. 293.

8. Charles E. Bidwell, "Librarian, Administrator, and Professor: Implications of Changing College Social Structures," in Libraries and the College Climate of Learning, ed. by Dan Bergen and E. D. Duryea (Syracuse: Syracuse University, $1964)$, p. 63.

9. Knapp, p. 292-295.

10. For a treatment of the status problems of academic research personnel see: Carlos E. Kruytbosch and Sheldon L. Messinger, "Unequal Peers: the Situation of Researchers at Berkeley," The American Behavioral Scientist, XI (May 1968), p. 33-43.

11. Elmer D. Johnson, Communication (New York: Scarecrow Press, 1966), p. 134.

12. Jane Forgotson, "The Staff Librarian Views the Problem of Status," College \& Research Libraries, XXII (July 1961). The librarian's “actual status is ... frequently ambiguous, with students and faculty alike regarding him as some kind of superclerk or administrative aid." (p. 275) "The faculty members are not alone in their doubts as to the librarian's role. The librarians themselves are confused, and so are the college administrators." (p. 280)

13. This trend has been the subject of considerable discussion in higher-education literature. Examples include: Dell Felder, "Independent-Study Practices in Colleges and Universities," Journal of Higher Education, XXXV (June 1964), p. 335338. Robert H. Beck and Robert C. McClure, "A University Looks to the Future," Journal of Higher Education, XXXIV (December 1963), p. 496-502.

14. Edwin E. Williams, "Bibliographical Control and Physical Dissemination," On Research Libraries: Statement and Recommendations of the Committee on Research Libraries of the American Council of Learned Societies (Cambridge: M.I.T. Press, 1969), p. 26-58.

15. Ibid.

16. Patrick Wilson, Two Kinds of Power: An Essay on Bibliographical Control (Berkeley: University of California Press, 1968), p. 150. He makes a very useful distinction between "descriptive" and "exploitive" bibliographical control. See also his description of "bibliographical therapists" who diagnose . . . the perhaps unfelt needs of scientific workers and the general public (and) satisfy those needs with suitable doses of literature." p. 144.

17. Ibid., p. 145. "A proper bibliographical policy would be one that was not passive, in the sense of providing the means by which those who felt a certain interest could satisfy it, but active, in the sense of supplying, unasked, those writings most likely to furnish what would improve the quantity and quality of work. This would be a policy for the most rational exploitation of writings, for the rationalization or making completely rational of the use of writings."

18. Proceedings of the Conference on the Research Library Sponsored by Daedalus and the Council on Library Resources (Boston: House of the American Academy of Arts and Sciences, 1966), Herman Fussler: "Take, for example, so mundane a matter as the competence of the scholar in his own bibliographical disciplinary areas. The evidence suggests that it is poor, and that the scholar is not really exploiting his own libraries very efficiently." p. 20.

19. J. Periam Danton, Book Selection and Collections (New York: Columbia University Press, 1963) p. 134-137. Cecil K. Byrd, "Subject Specialists in a University Library," College \& Research Libraries, XXVII (May 1966), p. 191-193, describes the successful program at Indiana University. Excellent more general discussions are: J. Periam Danton, "The Subject Specialist in National and University Libraries," Libri, XVII (1967), p. 42-58, and Robert P. Haro, "The Bibliographer in the Academic Library," Library Resources \& Technical Services, XIII (Spring $1969)$, p. $163-169$

20. Op. cit., p. 80 .

21. Amitai Etzioni, "Authority Structure and Organizational Effectiveness," Administrative Science Quarterly, IV (June 1959), p. 52.

22. Eli Ginzberg and Carol A. Brown, Manpower for Library Services (New York: Columbia University Conservation of Human Resources Project, 1967).

23. On Research Libraries, p. 24.

24. Education for Librarianship: Papers Presented at the Library Conference, University of Chicago, August 16-21, 1948, ed. Bernard Berelson (Chicago: American Library Association, 1949). Intellectual Foundations of Library Education (Chicago: University of Chicago Press, 1964). Major Problems in the Education of Librarians, ed. Robert D. Leigh (New York: Columbia University Press, 1954).

25. Lester E. Asheim, "Education and Manpower for Librarianship," ALA Bulletin, LXII (October 1968), 1101.

26. Samuel Rothstein, The Development of Reference Services Through Academic Traditions, Public Library Practice, and Special Librarianship (Chicago: American Library Association, 1955), p. 95-96.

27. Holbrook, p. 188-189.

28. William J. Goode, "The Librarian: from Occupation to Profession," ALA Bulletin, LXI (May 1967), 547. 